\begin{tabular}{|l|l}
\hline JuRNAL & JURNAL \\
\hline Pendidikan Dasar dan Keguruan \\
Volume 4, No. 2, 2019 \\
ISSN (print) $:$ :2527-578X \\
ISSN (Print) $:$ 2715-6818 \\
Homepage $\quad:$ http://journal.iaimsinjai.ac.id/index.php/JPDK \\
\hline
\end{tabular}

\title{
ANALYSIS DIKOTOMI PERSFEKTIF FERDINAND DE SAUSSURE SERTA ERVIN GOFFMAN DALAM KAJIAN STRUKTURALISME DAN POSITIVISME PRAGMATIK
}

\author{
Muhammad Syukri ${ }^{1}$ \\ ${ }^{1}$ Institut Agama Islam Muhammadiyah, Jl.Sultan Hasanuddin No 20, Sinjai, \\ Email: syukri.burhan@gmail.com.Telp:085255489112
}

\begin{abstract}
Abstrak
Filosofi bahasa berkaitan dengan sifat-sifat, asal usul, dan penggunaan bahasa. Sebagai sebuah topic, filosofi bahasa bagi para filsuf analitis berhubungan dengan empat masalah utama yaitu, makna, penggunaan bahasa, kognisi bahasa, dan hubungan diantara bahasa dan realitas. Metode library research dari berbagai sumber yang terkait dengan Analisis kebahasaan dari tokoh struktural modern Ferdinand de Saussure pada analisis langage, langue dan parole dengan membandingkan pandangan terori kebahasaan lainnya yaitu Irvin Goffman tentang postifisme dan dragmatis. Dari hasil penelitian menunjukkan bahwa Menurut Saussure, bahasa menggunakan tanda yang dimaknai secara konvensional. Tanda-tanda bahasa itu tersusun dalam rangkaian yang disebutnya rangkaian "sintagmatik". Dalam hal ini, tanda bahasa berada dalam relasi sintagmatik, yakni rangkaian tanda yang berada dalam ruang dan waktu yang sama atau relasi in praesentia. Disisi lain, Irving Goffman menyampaikan konsep impression management untuk menunjukkan usaha individu dalam menampilkan kesan tertentu pada orang lain. Konsep expression untuk individu yang membuat pernyataan dalam interaksi.
\end{abstract}

Kata Kunci: Filosofi Bahasa, Analisis Kebahasaan, Sintagmatik, Interaksi

\begin{abstract}
The philosophy of language is related to the nature, origin, and use of language. As a topic, the philosophy of language for analytical philosophers deals with four main problems namely, meaning, use of language, language cognition, and the relationship between language and reality. Library research methods from various sources related to linguistic analysis of modern structural figures Ferdinand de Saussure in langage, langue and parole analysis by comparing other linguistic terori views, namely Irvin Goffman on posifism and dragmatis. From the results of the study show that according to Saussure, language uses signs that are interpreted conventionally. The language signs are arranged in a series which he calls the "syntagmatic" series. In this case, the sign of language is in a syntagmatic relation, which is a series of signs that are in the same space and time or the relation in praesentia. On the other hand, Irving Goffman conveyed the concept of impression management to show the efforts of individuals in presenting certain impressions to others. The concept of expression for individuals who make statements in interactions.
\end{abstract}

Keyword: Language Philosophy, Linguistic Analysis, Syntagmatics, Interaction 


\section{Pendahuluan}

Penelitian ini diperlukan untuk memberi pemahaman teori-teori linguistik dari beberapa ahli, baik dengan melihat hubungannya maupun dari perfektif perbandingan pandangan terhadap aspek kebahasaan. Penelitian sebelumnya menunjukkan bahwa perhatian terhadap analisis kebahasaan secara lebih luas dan simbolik masih rendah. Sementara dalam sisi lain, filsafat bahasa berupaya memahami konsep-konsep yang diutarakan oleh bahasa serta mencari sistem pendukung yang efektif dan akurat. Tugas para filsuf sangat sulit karena mereka mencoba menemukan teori bahasa demi menghindari kesalahan dalam pemaknaan dan penggunaan konsep bahasa. Dalam berbagai aliran filsafat abad ke-20 hingga sekarang, seperti dalam fenomenologi, eksistensialisme Heidegger, filsafat analitik, neopositivisme (positivisme logis), hermeneutika dan semiotika, masalah bahasa memainkan peranan yang sangat besar (Hidayat, 2016: 1-5)

Filosofi bahasa berkaitan dengan sifat-sifat, asal usul, dan penggunaan bahasa. Sebagai sebuah topic, filosofi bahasa bagi para filsuf analitis berhubungan dengan empat masalah utama yaitu, makna, penggunaan bahasa, kognisi bahasa, dan hubungan diantara bahasa dan realitas.

Dalam kaitan ini analisis struktur bahasa tidak seharusnya dikelirukan dengan keterangan sebab akibat bagaimana sistem tersebut terwujud seperti adanya. Artinya bahwa sistem bahasa adalah fakta sosial dimana ada obyek-obyek kebendaan dan eksternal terhadap indovidu sehingga merupakan sistem-sistem nilai yang dikekalkan oleh konvensi sosial, Saussure (Lyons, 1932: 241).

Berkaitan dengan itu pada tulisan ini tokoh yang dibandingkan tersebut adalah Ferdinand De Saussure yang dikenal dengan teori strukturalisme dan yang lainnya adalah Erving Goffman yang dikenal dengan teori Dramaturgisnya. Dan tujuan dari pemaparan ini adalah untuk melihat bagaimana kedua tokoh ini menampilkan teori-teori kebahasaan atau teori lainnya yang secara interdisipliner terkait langsung dengan bidang kajian linguistik.

Sudah tentu kedua tokoh ini memiliki karakteristiknya masing-masing dalam mengargumentasikan pandangan mereka tentang bahasa, yaitu bagaimana membangun meta bahasa dengan ciri pendekatan teoritisnya. Sebagaimana kita ketahui bahwa Ferdinand de Saussure adalah salah satu ahli bahasa yang karya-karyanya sangat monumentalis dalam kontribusinya bagi perkembangan bidang linguistik di dunia, dengan sejumlah analisis-analisis penting dalam memandang bahasa sebagai alat komunikasi. Sedangkan Erving Goffman adalah sosok ilmuan Sosiologi yang juga memiliki kontribusi pada pengembangan linguistik dengan pendekatan media peran dalam berinteraksi sosial.

\section{Metode}

Dalam artikel ini, data dikumpulkan dengan metode library research dari berbagai sumber yang terkait dengan Analisis kebahasaan dari tokoh struktural modern Ferdinand de Saussure pada analisis langage, langue dan parole dengan membandingkan pandangan terori kebahasaan lainnya yaitu Irvin Goffman tentang postifisme dan dragmatis. Kedua pandangan teori kedua tokoh linguistik tersebut, melihatnya dalam persfektifnya masing-masing dalam semesta kebahasaan, baik dari sudut pandang struktural maupun dari pandangan positifisme dragmatis.

\section{Hasil dan Pembahasan}

\subsection{Ferdinand de Saussure "Bapak Strukturalisme"}

Tokoh ini berpengaruh besar dalam ilmu Linguistik. Dia disebut "bapak" strukturalisme karena mengadakan perubahan besar-besaran di bidang lingustik. Dia yang pertama kali merumuskan secara sistematis cara menganalisa bahasa, yang juga dapat dipergunakan untuk menganalisa sistem tanda atau simbol dalam kehidupan masyarakat, dengan menggunakan analisis struktural. Dalam buku yang berjudul Cours de Linguistique Generale, De Saussure (1959), ingin mengemukakan bahwa bahasa dapat dikaji dengan teori yang mandiri yang disebutnya "linguistique". Kalau kita melihat karya besar Saussure setidaknya ada 4 hal utama yang patut menjadi sorotan tentang keunggulan teorinya yaitu :

a) Teori Sosial tentang Bahasa dan Tanda Bahasa: Signifiant-Signifie 


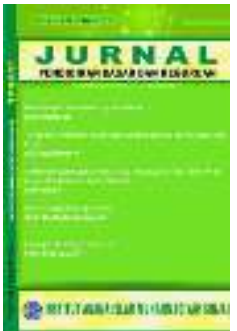

JURNAL

Pendidikan Dasar dan Keguruan

Volume 4, No. 2, 2019

ISSN (print) : 2527-578X

ISSN (Print) : :2715-6818

Homepage : http://journal.iaimsinjai.ac.id/index.php/JPDK

Bahasa adalah alat komunikasi dalam masyarakat yang menggunakan sistem tanda yang maknanya dipahami secara konvensional oleh anggota masyarakat bahasa yang bersangkutan. Tanda bahasa terdiri dari dua unsur yang tak terpisahkan yakni unsur citra akustik (bentuk) (signifiant/penanda) dan unsur konsep (signifie/petanda). Kedua unsur itu tak terpisahkan seperti dua sisi selembar kertas. Hubungan antara penanda sosial. Kedua unsur itu terdapat dalam kognisi para pemakai bahasa.

b) Hubungan Antartanda

Menurut Saussure (1959: 145-152), bahasa menggunakan tanda yang dimaknai secara konvensional. Tanda-tanda bahasa itu tersusun dalam rangkaian yang disebutnya rangkaian "sintagmatik". Dalam hal ini, tanda bahasa berada dalam relasi sintagmatik, yakni rangkaian tanda yang berada dalam ruang dan waktu yang sama atau relasi in praesentia. Contoh yang dapat kita berikan dari bahasa Indonesia adalah:

Ali --> makan --> nasi.

Urutan ketiga kata itu tidak bersifat sebarang, tetapi dipedomani oleh kaidah (langue) bahasa Indonesia. Jadi, arah panah pada contoh di atas tidak hanya memperlihatkan urutan (karena bahasa bersifat linear), tetapi juga hubunga fungsi sintaktis:

Subjek --> Predikat --> Objek.

Kata-kata (baca: unsur bahasa) yang berada dalam relasi sintagmatik tersusun dalam sebuah struktur. Kita dapat melihat pada kalimat di atas adanya struktur, yakni unsur-unsur (Ali, makan, nasi) yang masing-masing menempati "tempat kosong" yang kita sebut "gatra". Sesuai dengan kaidah (langue) Bahasa Indonesia, gatra dapat diisi oleh unsur bahasa tertentu. Jadi, gatra adalah "tempat kosong" yang terdapat sebelum, di antara dan sesudah panah, dalam contoh di atas, yang dapat kita sebut gatra:

(1) --> (2) --> (3).

Dalam sintaksis (1), (2), dan (3) masing-masing disebut fungsi sintaksis dan dalam hal ini setiap fungsi itu dapat diisi kata tertentu sesuai kaidah bahasa Indonesia. Dalam contoh yang pertama Ali --> makan --> nasi, gatra (1) dapat diisi oleh kata seperti Amat, Ida, ia, mereka atau kucing saya. Namun, kata-kata itu tidak dapat berada di ruang (dan waktu) yang sama. Hubungan antara kata-kata itu bersifat asosiatif.

Kata-kata yang dapat masuk ke dalam suatu gatra itu tergolong dalam kategori yang sejenis, biasanya dianggap masuk dalam paradigma yang sama. Hal yang sama juga terjadi pada makan yang memunyai relasi asosiatif dengan kata seperti menanak, menyendok dan membungkus nasi. Begitu seterusnya, setiap gatra hanya dapat diisi unsur bahasa yang memenuhi syarat tertentu.

Oleh karena itu relasi asosiatif kemudian disebut juga sebagai relasi paradigmatik. Pada tataran langue, setiap penutur bahasa menguasai semacam jejaring unsur-unsur bahasa yang terolong-golong dalam paradigma. Jadik, sekaligus semua unsur itu dapat saling membedakan diri. Jejaring ini disebut sistem.

c) Teori tentang "Langue" dan "Parole"

Dalam memahami bahasa sebagai alat komunikasi dan sebagai gejala sosial, de Saussure melihat ada dua tataran yang berkaitan satu sama lain. Bahasa sebagai gejala sosial disebut "langgage" yang terdiri atas dua tataran. Tataran pertama--pada tataran sosial atau lintas individu--adalah yang 


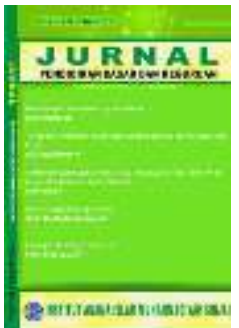

JURNAL

Pendidikan Dasar dan Keguruan

Volume 4, No. 2, 2019

ISSN (print) : 2527-578X

ISSN (Print) : :2715-6818

Homepage : http://journal.iaimsinjai.ac.id/index.php/JPDK

disebut "langue", yakni tataran konsep dan kaidah. Tataran dibawahnya adalah yang disebutnya "parole", yakni tataran praktik berbahasa dalam masyarakat.

Menurut de Saussure (1959: 85) langue (kaidah) menguasai parole (praktik berbahasa). Tanpa menguasai langue seorang tidak dapat ikut serta mempraktikan langage dalam sebuah masyarakat bahasa. Jadi, kita tidak akan dapat mempraktikan parole bahasa Urdu kalau kita tidak menguasai dulu langue dari langage Urdu. Konsep ini dapat diterapkan pada gejala nonverbal.

De Saussure memberi contoh yang sangat terkenal yaitu "permainan catur". Para pemain sebagai "komunitas pecatru" menguasai kaidah permainan tersebut, yakni langue, antara lain aturan tentang cara menjalankan setiap jenis bidak catur, misalnya "kuda" mengikuti gerakan "huruf L", "raja" hanya bisa bergerak satu kotak demi satu kota, "ratu" dapat bergerak melewati semua kotak kecuali berjalan secara diagonal, dan seterusnya. Kaidah itu mengarahkan bagaimana pecatur harus menjalankan bidaknya, yaitu parole.

d) Bahasa yang Utama adalah yang Lisan

Saussure (1959) meyakini bahwa bahasa tulis merupakan "turunan" dari bahasa lisan. Jadi bahasa yang utama adalah bahasa lisan. Bahasa yang sebenarnya adalah bahasa lisan. Ini merupakan kritik terhadap para peneliti bahasa yang terlampau terfokus pada bahasa tulis yang oleh de Saussure dipandang sebagai "tidak alamiah". Setelah berbicara tentang "langue" dan "parole" sebagai bagian dari "langage", de sussure membicarakan pentingnya bahasa lisan. "Langage" yang utama adalah bahasa lisan, yang merupakan objek kajian utama linguistik. Menurut Saussure, tulisan sering dianggap bahasa yang ;menurunkan bahasa lissan karena penelitian bahasa-bahasa kuno (seperti Yunani, Latin dan Sansekerta) memberikan citra bahwa bahasa tertulis lebih berprestise. Padahal tulisan adalah turunan dari bahasa lisan yang menurut de Saussure diatur oleh "langue", sedangkan tulisan merupakan sistem yang berbeda. Bahasa lisan juga dianggap yang utama karena menurut de Sussure makna lebih dekat pada yang lisan daripada yang tertulis. Objek kajian utama linguistik adalah bahasa lisan. Karena hubungan antara penanda dan petanda secara bersamaan membentuk tanda, keduanya tidak terlepas satu sama lain. Dengan demikian, keduanya membentuk satu kesatuan-yakni tanda--yang seringkali (konsep seperti ini) disebut struktur. Begitu pula hubungan antara "langue" dan "parole" (sebagai bagian dari "langage"), keduanya berkaitan satu sama lain secara tak terpisahkan, sehingga membentuk sebuah struktur, yakni "langage". Tentang struktur, Benny H. Hoed (2011), merasa bahwa yang diterangkan Noth dalam bukunya Handbook of Semiotics, sudah mencerminkan apa yang dikemukankan oleh Saussure dalam buku anumertanya. Noth mengemukakan bahwa ada dua jenis definisi tentang struktur, yakni yang "minimalis" dan yang "holistik".

Definisi minimalis berasal dari matematika, yakni "the set of relation connecting the elements of a system", yang kemudian dikenal dalam teori himpunan matematika. Jadi, struktur mencakupi konsep sistem. Dalam konsep de Sussure, struktur terwujud dalam dua pengertian, yakni relasi antar unsur sintagmatik dan asosiatif.

Relasi sintagmatik adalah relasi antara sejumlah unsur yang berkaitan satu sama lain dalam ruang dan waktu yang sama. Ini disebut juga sebagai relasi in praesentia. Unsur-unsur yang terdapat dalam relasi sintagmatik membentuk apa yang disebut struktur. Relasi asosiatif adalah relasi antara unsur dengan unsur lain yang diasosiasikan, jadi tidak dalam ruang dan waktu yang sama. Ini disebut juga sebagai relasi in absensia. Unsur-unsur yang berada dalam jejaring asosiatif membentuk sistem. Struktur dan sistem merupakan dua bangun yang selalu hadir dalam kognisi manusia. Ini kemudian menjadi dasar dari teori strukturalis atau pandangan yang dikenal dengan nama strukturalisme Saussure (1959: 219).

Definisi holistik melihat struktur sebagai suatu totalitas yang unsur-unsurnya berkaitan satu sama lain, baik in praesentia maupun in absentia. Piaget (1968) mengemukakan tiga sifat struktur, yakni (1) merupakan suatu totalitas, (2) dapat bertransformasi, dan (3) saat bertransformasi terjadi otoregulasi (membentuk relasi-relasi baru dalam struktur yang bersangkutan). 


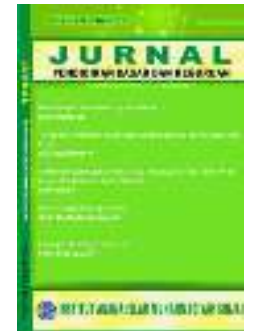

JURNAL

Pendidikan Dasar dan Keguruan

Volume 4, No. 2, 2019

ISSN (print) : 2527-578X

ISSN (Print) : 2715-6818

Homepage : http://journal.iaimsinjai.ac.id/index.php/JPDK

Oleh karena itu, prinsip dasar strukturalisme adalah bahwa (1) struktur dan sistem selalu hadir bersama, (2) struktur dans istem bersifat abstrak dan merupakan bangun (construct) yang adanya dalam kognisi maunisa, buakn sesuatu yang konkret, dan (3) struktur dan sistem merupakan satuan yang tertutup dan memenuhi dirinya sendiri.

Dalam kaitan ini menurut pandangan saya bahwa Saussure dalam menguraikan teorinya menggunakan ciri berbahasa :

1. Segmentatif yaitu mengemukakan asumsi kebahasaan secara mendetail dan mendasar yang dimulai dari unit-unit bahasa seperti halnya tentang bunyi, tuturan dan hasil dari tuturan dan persepsi sebagai hasil interaksi bahasa. Atau dikenal dengan Langue, Parole dan Langage.

2. Klasifikatif yaitu menampilkan aspek-aspek kebahasaan dengan mangklasifikasi unit-unti kebahasaan itu yang dimulai dari Bunyi, Kata, dan kalimat. Atau memandang bahasa dari unit yang paling konkrit hingga ke unit yang paling abstrak.

Dalam argumentasinya Saussure senantiasa memandang bahasa sebagai kumpulan dari dari tanda tanda diskusif yand dibagikan oleh sebuah komunitas. Bahasa bagi Saussure adalah modal interpretasi utama dunia, dan menuntut suatu ilmu yang disebut semiologi. Sehingga sifat penyampaiannya lebih paradigmatis dengan gaya bahasa metaforis dengan maksud memahami bahasa sebagai "Comunication Oriented". Jadi bagaimana menggunakan bahasa itu dalam konteksnya yaitu bahasa untuk diterima sebagai alat dalam interaksi.

Tanda-tanda linguistik mungkin, sampai batas yang bervariasi, akan berubah atau tidak berubah. Pencegah untuk mengubah linguistik meliputi: sifat sewenang-wenang dari tanda-tanda, banyaknya tanda-tanda yang diperlukan untuk membentuk bahasa, dan kompleksitas struktur bahasa. Faktor-faktor yang mendorong perubahan dalam bahasa meliputi: variasi individu dalam penggunaan bahasa, dan sejauh mana bahasa dapat dipengaruhi oleh kekuatan-kekuatan sosial.

\subsubsection{Keunggulan lain Saussure tentang Linguistik Sinkronik dan Diakronik}

Saussure (1959: 191-245) membedakan antara sinkronis (statis) linguistik dan (evolusi) diakronis linguistik. Linguistik sinkronis adalah studi tentang bahasa pada suatu titik waktu tertentu. Linguistik diakronis adalah studi tentang sejarah atau evolusi bahasa.

Menurut Saussure, perubahan berasal diakronik dalam kegiatan sosial Perubahan terjadi pada pola individu berbicara sebelum menjadi lebih luas diterima sebagai bagian dari bahasa. Berbicara adalah kegiatan yang melibatkan komunikasi lisan dan pendengaran antara individu. Bahasa adalah seperangkat aturan dimana individu dapat saling memahami.

Saussure mengatakan apa-apa yang masuk bahasa tertulis tanpa harus diuji dalam bahasa lisan.

${ }^{2}$ Bahasa diubah dengan menata ulang dan menafsirkan ulang unit nya. Unit adalah segmen dari rantai yang diucapkan yang sesuai dengan konsep tertentu. ${ }^{3}$ Saussure menjelaskan bahwa satuan bahasa dapat memiliki susunan sinkronis atau diakronis.

Investigasi Saussure tentang linguistik struktural memberi kita presentasi yang jelas dan ringkas dari pandangan bahwa bahasa dapat digambarkan dalam istilah unit struktural. Dia menjelaskan bahwa aspek struktural berarti bahwa bahasa juga merupakan suatu sistem nilai. Nilai linguistik dapat dilihat sebagai sebuah kualitas penanda, signified, atau tanda yang lengkap.

Nilai linguistik kata (penanda) berasal dari properti berdiri untuk suatu konsep (signified). Nilai menandakan berasal dari hubungannya dengan konsep lain. Nilai tanda yang lengkap berasal dari cara yang menyatukan signifier dan signified.

Dengan demikian, Saussure menunjukkan bahwa arti atau makna dari tanda-tanda yang didirikan oleh hubungan mereka satu sama lain. Tanda-tanda hubungan satu sama lain membentuk struktur bahasa. Sinkronis realitas ditemukan dalam struktur bahasa pada suatu titik waktu tertentu. Diakronis realitas ditemukan dalam perubahan bahasa selama periode waktu. Menurut Saussure, bahasa dilihat sebagai dualitas batin, yang dimanifestasikan oleh interaksi dari sinkronis dan diakronis, penanda, sintagmatik dan asosiatif dan ditandakan.

\subsubsection{Dikotomi Sintagmatis dan Asosiatif (paradigmatis)}


Saussure (1959: 219) mengemukakan bahwa hubungan dan perbedaan diantara unsur-unsur bahasa berlangsung dalam dua ligkungan yang berbeda, yang masing-masing diturunkan oleh tataran valensi tertentu. Hubungan antara apa yang menjadi bentuk dasar bahasa berupa unsur-unsur bunyi dan makna lebih disebut sebagai Langue dan hasil ujaran yang digunakan dalam berbahasa kemudian disebut sebagai parole dan gabungan dari keduanya dengan aturan atau norma yang digunakan dalam berbahasa yang kemudian disebut langage. Ciri dasar lain dari langue adalah susunannya yang linear dan berlangsung dalam waktu. Ini membedakannya dari sistem yang tanda-tandanya bersifat ruang. Hubungan dari penanda akuistis ini hanya ada dalam garis waktu karena unsur-unsurnya dilafalkan satu persatu dan membentuk suatu rangkaian. Jenis hubungan semacam ini disebut de Saussure sintagma. Sintagma dipertentangkannya dengan hubungan asosiatif dari tanda serupa yang dapat dipertukarkan dalam sintagma. Hubungan asosiatif dari tanda disebutnya paradigma.

Aspek sintagma dan paradigma bahasa harus dibedakan dari aspek perkembangan waktu. Dengan melihat perkembangan sepanjang masa, kita mengkaji bahasa dengan pendekatan diakronis. Di lain pihak dengan mengkaji bahasa pada suatu masa tertentu, kita mengkaji dengan pendekatan sinkronis.

Di mulai dengan dikotomi perole dan langue, de Saussure membedakan aspek intern dan ekstern dari linguistik. Sifat sistem intern bahasa digambarkannya melalui pembentukan satuan dalam oposisi dari penanda dan petanda, yang mendapatkan identitasnya melalui posisinya dalam struktur sistem tersebut. Tanda bahasa dibedakan de Saussure antara tanda bahasa semena absolut, tanda bahasa yang tidak semena absolut, dan tanda bahasa bermotivasi yang merupakan simbol. Sintagma linear bahasa, yang bersifat waktu, dipertentangkannya dengan asosiasi paradigma yang susunannya bersifat ruang.

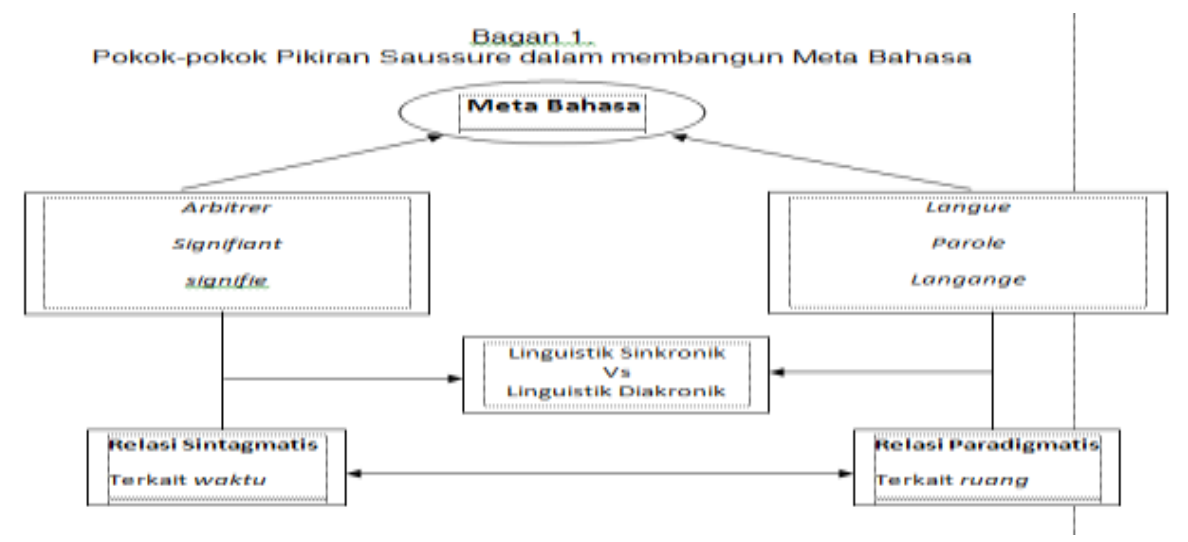

\subsection{Erving Goffman}

\subsubsection{Tokoh Positifisme dengan Dragmatis}

Erving Goffman (1974) terkenal dengan Teori Dramaturgisnya, melalui pendekatan ini Dia menggunakan bahasa dan khayalan teater untuk menggambarkan fakta subyektif dan obyektif dari interaksi sosial. Konsep-konsepnya dalam pendekatan ini mencakup tempat berlangsungnya interaksi sosial yang disebut dengan social establishment, tempat mempersiapkan interaksi sosial disebut dengan back region/backstage, tempat penyampaian ekspresi dalam interaksi sosial disebut front region, individu yang melihat interaksi tersebut disebut audience, penampilan dari pihak-pihak yang melakukan interaksi disebut dengan team of performers, dan orang yang tidak melihat interaksi tersebut disebut dengan outsider.

Ciri yang disebut dramaturgis dengan pendekatan Sosiologi ini, penekanannya adalah konsep menyeluruh bagaimana kita menghayati peran sehingga dapat memberikan feedback sesuai yang kita mau. Dramaturgis mempelajari konteks dari perilaku manusia dalam mencapai tujuannya dan bukan 


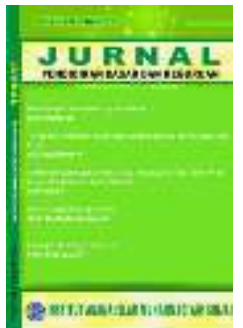

JURNAL

Pendidikan Dasar dan Keguruan

Volume 4, No. 2, 2019

ISSN (print) : 2527-578X

ISSN (Print) : :2715-6818

Homepage : http://journal.iaimsinjai.ac.id/index.php/JPDK

untuk mempelajari hasil dari perilakunya tersebut. Dramaturgi memahami bahwa dalam interaksi antar manusia ada "kesepakatan" perilaku yang disetujui yang dapat mengantarkan kepada tujuan akhir dari maksud interaksi sosial tersebut. Bermain peran merupakan salah satu alat yang dapat mengacu kepada tercapainya kesepakatan tersebut.

Tokoh ini juga menyampaikan konsep impression management untuk menunjukkan usaha individu dalam menampilkan kesan tertentu pada orang lain. Konsep expression untuk individu yang membuat pernyataan dalam interaksi. Konsep ini terbagi atas expression given untuk pernyataan yang diberikan dan expression given off untuk pernyataan yang terlepas. Serta konsep impression untuk individu lain yang memperoleh kesan dalam interaksi.

\subsubsection{Dramaturgis: "Kita Sebenarnya Hidup Di Atas Panggung"}

Teori dramaturgi menjelaskan bahwa identitas manusia adalah tidak stabil dan merupakan setiap identitas tersebut merupakan bagian kejiwaan psikologi yang mandiri. Identitas manusia bisa saja berubah-ubah tergantung dari interaksi dengan orang lain. Disinilah dramaturgis masuk, bagaimana kita menguasai interaksi tersebut. Dalam dramaturgis, interaksi sosial dimaknai sama dengan pertunjukan teater. Manusia adalah aktor yang berusaha untuk menggabungkan karakteristik personal dan tujuan kepada orang lain melalui "pertunjukan dramanya sendiri".

Dalam mencapai tujuannya tersebut, menurut konsep dramaturgis, manusia akan mengembangkan perilaku-perilaku yang mendukung perannya tersebut. Selayaknya pertunjukan drama, seorang aktor drama kehidupan juga harus mempersiapkan kelengkapan pertunjukan. Kelengkapan ini antara lain memperhitungkan setting, kostum, penggunakan kata (dialog) dan tindakan non verbal lain, hal ini tentunya bertujuan untuk meninggalkan kesan yang baik pada lawan interaksi dan memuluskan jalan mencapai tujuan. Oleh Goffman, tindakan diatas disebut dalam istilah "impression management". Goffman juga melihat bahwa ada perbedaan akting yang besar saat aktor berada di atas panggung ("front stage") dan di belakang panggung ("back stage") drama kehidupan. Kondisi akting di front stage adalah adanya penonton (yang melihat kita) dan kita sedang berada dalam bagian pertunjukan. Saat itu kita berusaha untuk memainkan peran kita sebaik-baiknya agar penonton memahami tujuan dari perilaku kita. Perilaku kita dibatasi oleh oleh konsep-konsep drama yang bertujuan untuk membuat drama yang berhasil (lihat unsur-unsur tersebut pada impression management diatas). Sedangkan back stage adalah keadaan dimana kita berada di belakang panggung, dengan kondisi bahwa tidak ada penonton.

Sehingga kita dapat berperilaku bebas tanpa mempedulikan plot perilaku bagaimana yang harus kita bawakan. Contohnya, seorang front liner hotel senantiasa berpakaian rapi menyambut tamu hotel dengan ramah, santun, bersikap formil dan perkataan yang diatur. Tetapi, saat istirahat siang, sang front liner bisa bersikap lebih santai, bersenda gurau dengan bahasa gaul dengan temannya atau bersikap tidak formil lainnya (merokok, dsb). Saat front liner menyambut tamu hotel, merupakan saat front stage baginya (saat pertunjukan). Tanggung jawabnya adalah menyambut tamu hotel dan memberikan kesan baik hotel kepada tamu tersebut. Oleh karenanya, perilaku sang front liner juga adalah perilaku yang sudah digariskan skenarionya oleh pihak manajemen hotel. Saat istirahat makan siang, front liner bebas untuk mempersiapkan dirinya menuju babak ke dua dari pertunjukan tersebut. Karenanya, skenario yang disiapkan oleh manajemen hotel adalah bagaimana sang front liner tersebut dapat refresh untuk menjalankan perannya di babak selanjutnya. Sebelum berinteraksi dengan orang lain, seseorang pasti akan mempersiapkan perannya dulu, atau kesan yang ingin ditangkap oleh orang lain. Kondisi ini sama dengan apa yang dunia teater katakan sebagai "breaking character". Dengan konsep dramaturgis dan permainan peran yang dilakukan oleh manusia, terciptalah suasana-suasana dan kondisi interaksi yang kemudian memberikan makna tersendiri. Munculnya pemaknaan ini sangat tergantung pada latar belakang sosial masyarakat itu sendiri. Terbentuklah kemudian masyarakat yang mampu beradaptasi dengan berbagai suasana dan corak kehidupan. Masyarakat yang tinggal dalam komunitas heterogen perkotaan, menciptakan panggung-panggung sendiri yang membuatnya bisa tampil sebagai komunitas yang bisa bertahan hidup dengan keheterogenannya. Begitu juga dengan 
masyarakat homogen pedesaan, menciptakan panggung-panggung sendiri melalui interaksinya, yang terkadang justru membentuk proteksi sendiri dengan komunitas lainnya. Apa yang dilakukan masyarakat melalui konsep permainan peran adalah realitas yang terjadi secara alamiah dan berkembang sesuai perubahan yang berlangsung dalam diri mereka. Permainan peran ini akan berubah-rubah sesuai kondisi dan waktu berlangsungnya. Banyak pula faktor yang berpengaruh dalam permainan peran ini, terutama aspek sosial psikologis yang melingkupinya.

\subsubsection{Kritik Terhadap Dramaturgi}

Dramarturgi hanya dapat berlaku diinstitusi total dimana institusi ini maksudnya adalah institusi yang memiliki karakter dihambakan oleh sebagian kehidupan atau keseluruhan kehidupan dari individual yang terkait dengan institusi tersebut, dimana individu ini berlaku sebagai sub-ordinat yang mana sangat tergantung kepada organisasi dan orang yang berwenang atasnya. Ciri-ciri institusi total antara lain dikendalikan oleh kekuasan (hegemoni) dan memiliki hierarki yang jelas. Contohnya, sekolah asrama yang masih menganut paham pengajaran kuno (disiplin tinggi), kamp konsentrasi (barak militer), institusi pendidikan, penjara, pusat rehabilitasi (termasuk didalamnya rumah sakit jiwa, biara, institusi pemerintah, dan lainnya. Dramaturgi dianggap dapat berperan baik pada instansiinstansi yang menuntut pengabdian tinggi dan tidak menghendaki adanya "pemberontakan". Karena di dalam institusi-institusi ini peran-peran sosial akan lebih mudah untuk diidentifikasi. Orang akan lebih memahami skenario semacam apa yang ingin dimainkan. Bahkan beberapa ahli percaya bahwa teori ini harus dibuktikan dahulu sebelum diaplikasikan. Menihilkan "kemasyarakatan"

Teori ini juga dianggap tidak mendukung pemahaman bahwa dalam tujuan sosiologi ada satu kata yang seharusnya diperhitungkan, yakni kekuatan "kemasyarakatan". Bahwa tuntutan peran individual menimbulkan clash bila berhadapan dengan peran kemasyarakatan. Ini yang sebaiknya dapat disinkronkan. Dianggap condong kepada Positifisme

Dramaturgi dianggap terlalu condong kepada positifisme. Penganut paham ini menyatakan adanya kesamaan antara ilmu sosial dan ilmu alam, yakni aturan. Aturan adalah pakem yang mengatur dunia sehingga tindakan nyeleneh atau tidak dapat dijelaskan secara logis merupakan hal yang tidak patut.

\subsubsection{Analisa Dramaturgi}

Dramaturgis masuk dalam Perspektif Obyektif, Dramaturgis dianggap masuk ke dalam perspektif obyektif karena teori ini cenderung melihat manusia sebagai makhluk pasif (berserah). Meskipun, pada awal ingin memasuki peran tertentu manusia memiliki kemampuan untuk menjadi subyektif (kemampuan untuk memilih) namun pada saat menjalankan peran tersebut manusia berlaku objektif, berlaku natural, mengikuti alur. Misalnya, pada kasus Kekerasan pada Rumah Tangga ("KDRT"), saat perilaku kekerasan itu hendak terjadi, korban sebenarnya memiliki pilihan, berserah diri atau melakukan perlawanan. Bila ia memberontak maka konsekuensinya adalah ini dan bila ia pasrah maka akibatnya seperti itu. Proses subyektif ini akan beralih menjadi obyektif saat ia menjalani peran yang dipilihnya tersebut. Misalnya yang ia ambil adalah pasrah karena ia takut kalau ia melarikan diri konsekuensinya lebih parah, atau ia merasa terlalu tergantung kepada tersangka dan mengkhawatirkan nasib anaknya bila ia melawan. Maka, setelah itu ia akan menjalani perannya sebagai korban. Secara naluriah ia akan menutupi bagian tubuhnya yang mungkin menjadi sasaran kekerasan. Atau ia berusaha untuk menutupi telinganya untuk melindungi mental dan psikologisnya. Itulah mengapa dramaturgi di sebut memiliki muatan objektif. Karena pelakunya, menjalankan perannya secara natural, alamiah mengetahui langkah-langkah yang harus dijalani.

Pendekatan Keilmuan Little John - Pendekatan Scientific (ilmiah - empiris), Seperti telah dijabarkan diatas, Dramaturgis merupakan teori yang mempelajari proses dari perilaku dan bukan hasil dari perilaku. Ini merupakan asas dasar dari penelitian-penelitian yang menggunakan pendekatan scientific. Obyektifitas yang digunakan disini adalah karena institusi tempat dramaturgi berperan adalah memang institusi yang terukur dan membutuhkan peran-peran yang sesuai dengan semangat 
Volume 4, No. 2, 2019

ISSN (print) : 2527-578X

ISSN (Print) : 2715-6818

Homepage : http://journal.iaimsinjai.ac.id/index.php/JPDK

institusi tersebut. Institusi ini kemudian yang diklaim sebagai institusi total sebagaimana telah dijabarkan sebelumnya.

Bahwa hasil dari peranan itu sesungguhnya, bila proses (rumusnya) dijalankan sesuai dengan standar observasi dan konsistensi maka bentuk akhirnya adalah sama. Contohnya, bila seorang pengajar mempraktekkan cara mengajar sesuai dengan template perguruan tinggi maka kualitas keluaran perguruan tinggi tersebut akan menghasilkan kualitas yang bisa dikatakan relatif sama. Atau untuk contoh front liner hotel diatas, bila front liner dapat memainkan skenario penyambutan tamu manajemen hotel, niscaya tamu akan merasa dihargai, dihormati, senang dan bersedia untuk datang menginap kembali di hotel tersebut.

Dari gambaran singkat diatas, maka dapat dibuat kerangka pikir teori dramaturgis seperti dibawah ini

Bagan 2

Kerangka Pikir Teori Dramaturgis

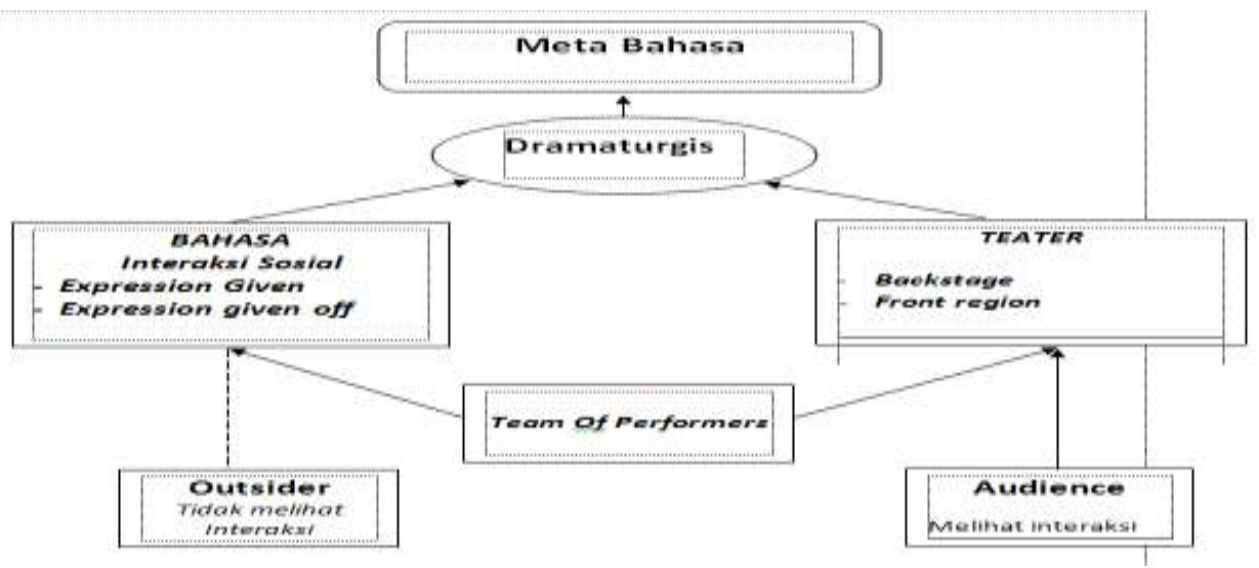

\section{Simpulan}

Maka berdasarkan pada cara asumsi teoritis dari kedua tokoh linguis tersebut, dapatlah dikemukakan perbedaan mendasar yaitu: Bagi Saussure bahasa adalah alat komunikasi dalam masyarakat yang menggunakan sistem tanda yang maknanya dipahami secara konvensional oleh anggota masyarakat yang bersangkutan, Bagi Erving Goffman dalam mempelajari interaksi antar manusia ada "kesepakatan" perilaku yang disetujui yang dapat mengantarkan kepada tujuan akhir dari maksud interaksi sosial tersebut melalui cara memainkan peran, Kedua Tokoh ini memandang sistem komunikasi yang berlaku atau tumbuh di masyarakat adalah sebuah norma yang di tetapkan melalui konvensi atau kesepakatan antar manusia yang menjadi subyek di dalam sistem komunikasi itu, Bagi Saussure bahasa yang utama adalah bahasa lisan karena beliau beranggapan bahwa bahasa tulisan adalah turunan dari bahasa lisan. Selain itu, menurutnya bahwa makna lebih dekat pada yang lisan dari pada yang tulis dan objek kajian utama linguistic adalah bahasa lisan, Bagi Erving Goffman pola interaksi dalam masyarakat adalah bersifat natural, alamiah artinya peran yang ada pada manusia adalah berterima atas segala ketetapan yang sudah ada dan telah di sepakati bersama. Model analisis bahasa yang ditonjolkan oleh Sassure adalah structuralism yaitu : mengidentifikasi unsur-unsur yang bersesuaian untuk menyampaikan pesan. Seperti bahasa yang selalu terdapat unsur-unsur mikro untuk menandainya, salah satunya adalah bunyi atau cara pengucapan. Sedangkan model analisis Erving Goffman lebih condong kepada positivism 
\begin{tabular}{|l} 
JURNAL \\
\hline JURNAL \\
Pendidikan Dasar dan Keguruan \\
Volume 4, No. 2, 2019 \\
ISSN (print) : 2527-578X \\
ISSN (Print) : 2715-6818 \\
Homepage $\quad:$ http://journal.iaimsinjai.ac.id/index.php/JPDK \\
\hline
\end{tabular}

\section{Daftar Pustaka}

Barthes, Roland translated by AnnetteLavers. (1972). Mythologies. New York: The Noonday Press.

De Saussure, Ferdinand edited by Charles Bally and Albert Sechehaye. (1959). Course in General Linguistics 3rd ed. New York: Philosophical Library.

Hidayat, Ahmad Asep (2016). Filsafat Bahasa; Mengungkap Hakikat Bahasa, Makna dan Tanda. PT Remaja Rosdakrya, Bandung.

Newell, A. \& Simon, H. (1972). Human Problem Solving. Englewood Cliffs, NJ: Prentice Hall.

Lyons, J. (1932). Bahasa dan Linguistik. Diterjemahkan oleh Ramli Salleh, Toh Kim Hoi. Dewan Pustaka dan Bahasa. Selangor Darul Ihsan.

Goffman, Erving. (1974) Frame Analysis: An Essay On the Organization of Experience.

Sobur, Alex. (2004). Analisis Teks Media: Suatu Pengantar untuk Analisis Wacana, Analisis Semiotik, dan Analisis Framing. Bandung: Remaja Rosdakarya. 